\title{
Factors affecting quality of goat's milk yogurt
}

\author{
Elisaveta Sandulachi \\ Departament of Food Products \\ Viorica Bulgaru \\ Departament of Food Products
}

\begin{abstract}
A comparative study of the quality and nutritional value of Moldova's cow and goat milk is presented. Organoleptic properties (taste, odor, appearance, color), physicochemical indicators (acidity, fat content, protein, viscosity, Q10 value et at.) microbiological indices (total number of colony forming units, Listeria monocytogenes, Staphylococcal Enterotoxin, Salmonella, Enterobacteriaceae, Bacillus cereus), the presence of antibiotics and preservatives. The study includes the microbiological analysis of milk according to the season. Starter cultures were tested for temperature, light, $\mathrm{O}_{2}$ access. The article presents and argues the factors determining the quality of cow milk and goat milk, the technological scheme for the manufacture of yogurt by the thermostat method, and its quality indexes (organoleptic, physico-chemical and microbiological).
\end{abstract}

Keywords: Goat's milk, cow milk, lactic bacteria, starter culture, fermented milk

\section{INTRODUCTION}

Acid dairy products are popular all over the world, both because of their sensory characteristics and the potential they have for maintaining and even improving the consumers health. Obtaining world quality products, diversifying the range of acid dairy products involves the use of new ingredients and processes, less familiar to the country's milk processing sector. The technology of the fermented dairy products allows to use as a raw material milk obtained from different breeds of animals. In this context, goat milk due to the balanced chemical composition is a suitable raw material for dairy products manufacture.

The quality and chemical composition of goat's milk are directly related to the breed, the lactation period, the physiological and genetic aspects of the animal. In addition, the characteristics of goat milk may vary as a result of feed composition, maintenance conditions and environmental conditions of each country and region (Peres et al 2016; HernándezLedesma et al 2011; Park et al 2007). Goat milk differs from cow or human milk in higher digestibility, distinct alkalinity, higher buffering capacity, and certain therapeutic values in human medicine and nutrition (Park 2017, 1994). Although there are certain species-specific differences in composition of milk, the basic nutrient composition of goat milk is similar to that of cow milk. Caprine milk, on the average, contains $12.2 \%$ total solids, consisting of $3.8 \%$ fat, $3.5 \%$ protein, $4.1 \%$ lactose and $0.8 \%$ ash (Table 1), indicating that it has more fat, protein and ash, and less lactose than cow milk (Park 2017, 1994). 
Table 1. Basic composition of goat, cow and human milks

\begin{tabular}{|l|c|c|c|}
\hline $\begin{array}{c}\text { Constituents, } \\
(\mathrm{mean} \text { values per } 100 \mathrm{~g})\end{array}$ & Goat & Cow & Human \\
\hline Fat $(\mathrm{g})$ & 3.8 & 3.6 & 4 \\
\hline Protein $(\mathrm{g})$ & 3.5 & 3.3 & 1.2 \\
\hline Lactose $(\mathrm{g})$ & 4.1 & 4.6 & 6.9 \\
\hline Ash $(\mathrm{g})$ & 0.8 & 0.7 & 0.2 \\
\hline Total Solids $(\mathrm{g})$ & 12.2 & 12.3 & 12.3 \\
\hline Calories (cal) & 70 & 69 & 68 \\
\hline
\end{tabular}

Data from (Park, 2017, Haenlein and Caccese 1984, Jenness 1980, USDA 1976).

According to the world's statistical data, the largest amount of goat's milk is used for cheeses. However, goat's milk is used to manufacture a range of various dairy products including fermented dairy products, with major US and New Zealand manufacturers (Pereset al 2016).

Thanks to well-balanced chemical composition, curative properties, nutritional effects, toning, antianemic and anti-infectives, fine curd formation and high digestibility goat milk perfectly fit among the products recommended for children's nutrition. The use of goat's milk in acidic dairy products assortment can highlight all its beneficial properties complete with a positive impact on the gastrointestinal tract due to the finished product microbiota (Taftă 1996).

The primary concern of nutrition specialists is to replace breast milk to a dairy product that is as close as possible to its composition. Milk has a key role in the nutrition and development of the human body, even in the first year of life.

However, some specialists in the field emphasize that the milk of animal origin cannot be compared to the mother's milk in terms of nutrient content and balance. But the easily assimilable fat content and casein that form a homogeneous and soft curd compared to casein of cow's milk make it possible for goat milk to be consumed among children with cow's milk allergies and digestive tract problems (Aliagaet al 2000).The amount of short-chain fatty acids (glycerol ethers) in the goat's milk fat is higher than in cow's milk, important for the nutrition of the newborn (James 2015). Also, the goat's milk fat is more easily digestible, and can be considered an important source used in various metabolic processes, and even for combating some metabolic diseases (Alfe' Rez et al 2001, Haenleinet al 2001). Goat milk proteins are more easily digestible than cows' milk proteins. Goat milk has lower casein content and a lower coagulation capacity. This difference in coagulation power is attributed to low levels of $\alpha_{s 1^{-}}$ casein in goat milk compared to cow's milk, being a key reason for goat's milk to be considered as more easily digested than cow's milk. Casein of breast milk is completely hydrolyzed, compared with $96 \%$ casein from goat milk and 76-90\% casein from cow's milk. The result is attributed to the higher level of $\beta$-casein and a lower level of $\alpha_{s 1}$-casein in casein of human and goat milk (Bulgaru et Botezat 2018, Bevilacqua 2001).

Milk is a source of the important micro- and macroelements easily assimilated by the organization. In children's diet, dairy products are an important source of minerals such as calcium, magnesium, selenium and vitamins. The goat's milk is richer in calcium, phosphorus, citric acid, potassium and magnesium, and high in vitamin $A$ is indicated in the children and the elderly diet (Tilahum et al 2003). Reaction of goat's milk is alkaline, just like breast milk, while cow's milk produces an acidic reaction. An acidic environment stimulates the growth of bacteria, fungi and viruses (Tilahum et al 2003, Sandulachi and Bulgaru, 2016). Goat milk is often consumed by young children, the elderly, those who are ill, or have cow milk allergy and low tolerance to cow milk. The use of goat milk as a hypo-allergenic infant food or milk 
substitutein infants allergic to cow milk has been reported in much literature (Bulgaruet Botezat 2018, Park et al 2007, Jenness 1980).

The disadvantage of goat milk when used in the production of fermented dairy products is the possibility of the specific goat milk taste appearance, this problem can be improved by keeping the animals hygienically (Peres et al 2016, Jenness 1980, Park et al 2006).

The volume of goat milk production has been dramatically increased in the past two decades (Haenlein, 1992, Jenness 1980) and worldwide production of goat milk has been risen by approximately 60\% between 1993 and 2013 (FAOSTAT, 2013).

In recent years, the increase of the goat breeds for milk production has increased in the Republic of Moldova. The development of this branch of industry comes as an advantage to cover the shortage of raw material from cow's milk, which has tended to decrease in recent years (Figure 1). There are several small businesses in the country that come to develop the assortment of products using raw goat milk as raw material.

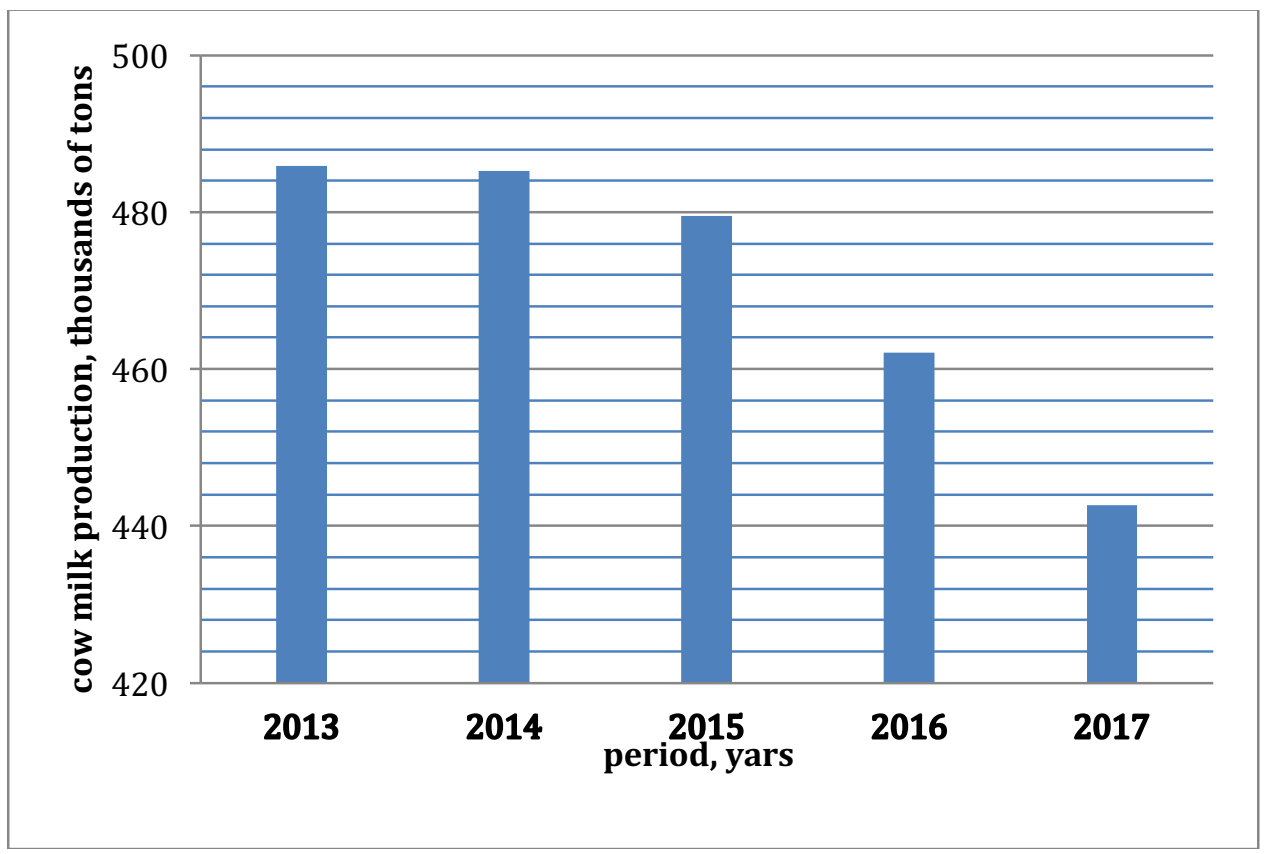

Figure 1. Production of cow's milk, (thousands of tons), (statistca.md)

Fermented dairy products are made from milk and / or dairy products by the action of specific microorganisms that cause $\mathrm{pH}$ reduction and coagulation. The microorganisms used must be viable, active and important in the finished product at the time of sale to the consumer.Milk is a slightly perishable product. The microbiota of milk is generally formed by non-pathogenic microorganisms as well as those pathogens (Jandal 1996, Haenlein 1987). Non-pathogenic micro-organisms include lactic bacteria, widely distributed in nature, which play an important role in the fermentation of many foods and feeds. By contamination of the saprophytic germs, the risk of pathogenic germs is also increased. Many of the pathogenic bacteria do not multiply in milk (Mycobacterium tuberculosis, M. bovis, Brucella, Rickettsia), their danger depending on the initial degree of milk contamination, its subsequent dilution, the thermal treatments, the time to milk consumption. Other pathogenic germs (Staphylococcus aureus, Streptococcus pyogenes, Escherichia coli, etc.) can be multiplied into milk. The metabolic activity of most pathogenic germs is inhibited at low temperatures, so it is very important to immediately cool the milk after obtaining it until its thermal treatment (Barzoi et al. 2002). 
This work includ a case study on the goat milk exploitation for the children yogurt manufacture. The factors that determine the yogurt quality have been analyzed. Research has been carried out within the national project for young researchers named Physico-chemical and technological features synthesis of localgoat milk in order to exploit it.

\section{Materials}

\section{MATERIALS AND METHODS}

Raw goat milk was received according to the Moldavian standard SM: 2015, adopted on 29.09.2015. Raw goat and sheep milk. Specifications. This standard establishes technical conditions for the quality of raw goat and sheep milk collected for industrial processing.

Row cow milkwas received according to the Moldavian standard SM 104 and Guvernamental Decision No. 611 with regard to the approval of the Technical Regulation "Milk and dairy products" that included technical conditions for the quality of raw cow milk collected for industrial processing.

Lyophilized starter culture type YO-MIX 485 LYO 200 DCU was used. Dosage 10-20 DCU / 100 liters. Composition: lactobacillus delbruekii ssp. Bulgaricus, Streptococcus thermophilus. Additions of sucrose and maltodextrin.

Drinking water according to HG - 934 of 15.08 .2007$.

For microbiological control werw used the following medius:

Mediu Levine EMB Agar (eosine methylene-blue lactose agar). Application: for the isolation and differentiation of bacteria Escherichia coli and Enterobacter, but also for the rapid identification of Candidei albicans. Nutrient agar, Nutrient bulion. Application: are used as universal medium for the cultivation of less demanding microorganisms. Both medius used for food examination.

Bulion bila brilliant green 2\%. Application: is used for selective enrichment and counting of bacteria Escherichia coli and other fecal coliforms from water, milk, food and other organic matters. Mediu with malt extract. Application: for growing mushrooms and yeasts. Is stored at $20^{\circ} \mathrm{C}$. Mediu with potato dextrose (glucose). Application: Is used for the cultivation, isolation and counting of yeasts and molds in food and other organic matter. Is stored at $+20^{\circ} \mathrm{C}$.

Mediu VRBG (Violet red bile glucose). Application: is a selective mediu for the isolation and counting of all enterobacterial species in water, food. Is stored at $20^{\circ} \mathrm{C}$. Mediu Plate count agar

Application: is mainly used to determine the microbial total contained in milk, dairy products, water and other organic matter. Is stored at $20^{\circ} \mathrm{C}$. MRS Agar lactobacillus. Application: for the detection, isolation and counting of bacteria of the Lactobacillus genus. Store at temperatures between $2^{\circ} \mathrm{C}$ and $8^{\circ} \mathrm{C}$.

\section{Methods}

\section{Organoleptic methods}

Appreciation of sensory quality based on the score scale. Method principle: Evaluation of each organoleptic characteristic by comparison with scoring scales of $0 \ldots 5$ points and obtaining the average score of the tasters group, (ISO 6658: 2005).

$$
P_{m p}=P_{m n p} \times f_{p}
$$

where: $P_{m n p}$ - Unmatched average score (arithmetic mean of results); 
$f_{p}$ - the weight factor (shows how a sensory character carries the total sensory quality of the product).

$$
P_{t p}=\sum P_{m p}
$$

\section{Physico-chemical methods}

Titratable acidity determination according to DIN 10316 and in yoghurt according to ISO/TS 11869 and IDF/RM 150.

Determination of fat content by the gravimetrică method, (SM EN ISO 1211:2015).

Determination of milk protein content. Kjeldah method ISO 8968-1:2014 - IDF 20-1:2014.

The viscosity of the acid dairy products determined by the Brookfield DV-III rotary viscometer.

Determination of total dry matter content. (MAC Humidity Analyzer, Radwag).

Determination of Yoghurt Syneresis Index. The principle of the method consists in the separation between solid phase (gel) and liquid during coagulation of milk as a result of active physicochemical phenomena (casein network restructuring) and passive (porosity and permeability of the gel) (Hassan et al 2015).

$$
S=\frac{m_{z}}{m_{p}} \times 100
$$

Where: $\mathrm{m}_{\mathrm{z}}$ - the amount of exuded whey, g;

$\mathrm{m}_{\mathrm{p}}$ - sample mass, $\mathrm{g}$;

$\mathrm{S}-$ syneresis index, \%.

\section{Q10 value}

Shelf-life studies can come in many different forms, including accelerated studies. In these studies, accelerated conditions (i.e. elevated temperature) are applied to eligible products to predict product shelf-life at typical storage conditions. This process is performed using the $\mathrm{Q}_{10}$ value. The $\mathrm{Q}_{10}$ value of a product is the temperature quotient for a $10^{\circ} \mathrm{C}$ temperature difference, as expressed in the equation below (Concept of Accelerated Shelf Life Study):

$$
Q_{10}=\frac{\text { Shelf-life at temperature } T\left({ }^{\circ} \mathrm{C}\right)}{\text { Shelf-life at temperature } T\left({ }^{\circ} \mathrm{C}\right)+10^{\circ} \mathrm{C}}
$$

\section{Microbiological methods}

Acceptable levels of microbial content in milk-based infant formulas in the Customs Union Technical Regulation "Concerning the safety of milk and dairy products TR TC 033/2013.

The total number of microorganisms was performed in accordance with SMER EN ISO 4833: 2014, the horizontal method for microorganisms enumeration (SM EN ISO 4833-1:2014).

The presence of yeast and mold fungus in $1 \mathrm{~cm}^{3}$ of finished products is not admissible. The analysis is carried out in accordance with (Sandulachi et al 2017).

Diagnostic methods shall be in accordance with the provisions of MS SR ISO 21528-1: 2014 and MS SR ISO 21528-2: 2011 - Enterobacteriaceae; SM SR EN ISO 11290-1- Listeria monocitogenes; 
SM SR EN ISO 6888-1: 2011 - Coagulase-positive staphylococcus; SM SR EN ISO 6579: 2015 Salmonella.

GD no. 221 of 2009 on the approval of the Rules on Microbiological Criteria for Foodstuffs.

The rules on microbiological criteria for foodstuffs lay down microbiological criteria for certain micro-organisms and the enforcement mechanisms that food business operators must comply with when implementing general and special hygiene measures.

Table 2. Microbiological criteria for infants milk products

\begin{tabular}{|c|c|c|}
\hline \multirow{2}{*}{$\begin{array}{l}\text { Microorganisms / toxins } \\
\text { and their metabolites }\end{array}$} & Limits & \multirow[t]{2}{*}{ Analytical reference methods } \\
\hline & maximum & \\
\hline \multicolumn{3}{|c|}{ Safety criteria of infants dairy products } \\
\hline Listeria monocytogenes & Absence in $25 \mathrm{~g}$ & EN/ISO 11290-1 \\
\hline Enterotoxine stafilococice & Absence in $25 \mathrm{~g}$ & $\begin{array}{l}\text { European method of CRL selection for } \\
\text { coagulase-positive staphylococci }\end{array}$ \\
\hline Salmonella & Absence in $25 \mathrm{~g}$ & EN/ISO 6579 \\
\hline \multicolumn{3}{|c|}{ Hygiene criteria for the production process } \\
\hline Enterobacteriaceae & Absence in $10 \mathrm{~g}$ & ISO 21528-1 \\
\hline Bacillu cereus prezumtiv & $500 \mathrm{ufc} / \mathrm{g}$ & EN/ISO 7932 \\
\hline
\end{tabular}

Betastar Combo is a test for the rapid detection of beta-lactam / cephalosporin antibiotics (eg penicillin, ampicillin, cephalonium, etc.) and tetracyclines in cow, goat and sheep milk. (www.biocult.ro/produse/produse-pentru-industria-laptelui).

Determination of somatic cell number according to SR SR EN ISO 13366-2 or SR SR EN ISO 18330.

Determination of pasteurization (phosphatase assay) according to SM EN ISO 22160 or GOST 3623.

SM EN ISO 22160: 2015 Milk and milk based drinks. Determination of alkaline phosphatase activity. Method (EPAS) with enzymatic photoactivation system.

\section{RESULTS AND DISCUSSIONS}

The assortment of dairy products in the world and especially in Moldova is diverse. Every year there are about eight thousand new food products, of which one third are dairy products. The basic problem of specialists and producers of food is to create the possibility of competition by high indicators of quality and safety of human health, to satisfy consumer demands and competitive price (Bulgaru V. 2017, Patermann 2005, Ried 2004, Senderov 1998).

Goat milk is widely used for home consumption worldwide and used to produce different cheeses and yoghurt. Quality of raw materials (milk) depends on variability in protein, lactose, fat and microbial flora, variability in breeds of cattle, season and region, milking and storage conditions the farm. Quality criteria for raw milk: Low natural microflora; Free from antibiotics, sanitizing chemicals; No contamination from mastitis milk and colostrums; Free from rancidity; Free from bacteriophages; Free from hormones; Stored below $5^{\circ} \mathrm{C}$.

The estimation of the milk type quality indices values is necessary to choice the next technological treatments and its distribution at the commercial market.

The results of the goat's and cow's milk quality indices are presented in Table 3. 
Table 3. Characteristics of the goat milk and cow's milk quality indices

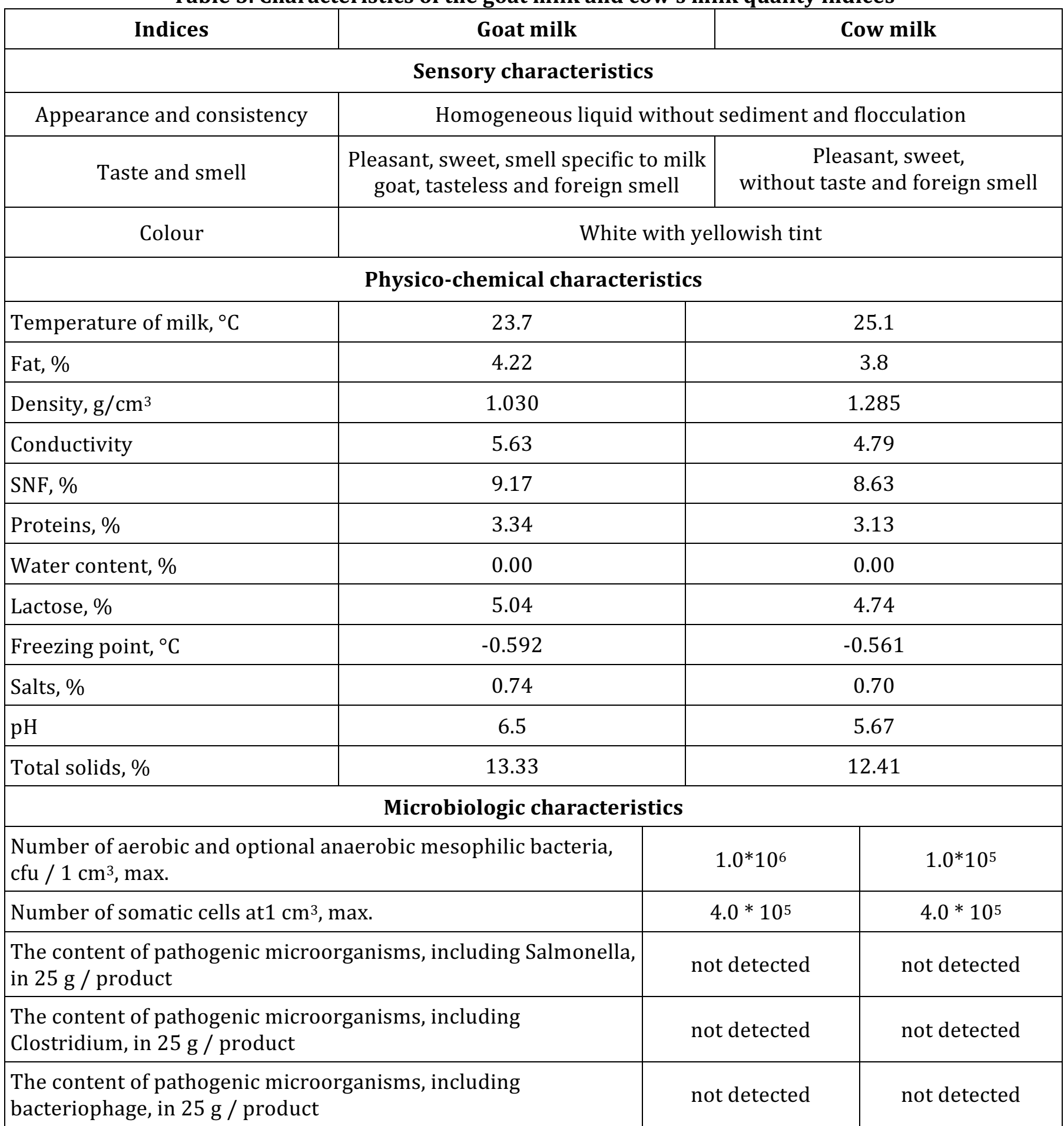

The total number of mesophilic bacteria obtained during the microbiological analysis shows that the milk collected from the farms was of good hygienic quality. Milk had no signs of mastitis, intramammary infections and faecal contamination during milking. The total number of germs obtained for goat milk do not exceed the limits included in the normative documents (EC Regulation no.1662 / 2006). For the whole period of microbiological quality analysis of goat milk values between 4.66-4.7 log cfu/ ml were obtained, the maximum values being recorded in the summer months.

In summer, milk quality decreases, possibly due to the distribution of microelements in the soil. Numerous studies have shown that high concentrations of microelements in soil can be 
accumulate in plants. This indicates a higher risk of penetration of the microelements $(\mathrm{Cu}, \mathrm{Pb}$, $\mathrm{Zn}, \mathrm{Cd}$ ), considered heavy metals, in the food chain. Since heavy metals exert germicidal effects, they "can rapidly destroy many types of microorganisms, including vegetative forms of bacteria, but not endospori" (Ivana, 2011). The microflora encountered in goat's milk varies depending on the places of animals grazing, but the content of microelements in soil does not decisively influence this.

The results obtained correspond to the findings made by other authors (Foschino et al.,2002), which studied the microbiological quality of goat milk in the Bergamo area of Italy and reported an average of $4.7 \mathrm{log} \mathrm{cfu} / \mathrm{ml}$. Muehlherr et al., 2003 for goat milk collected from farms in Switzerland reported an average of $4.97 \mathrm{log} \mathrm{cfu} / \mathrm{ml}$ (Cupakova, 2012).

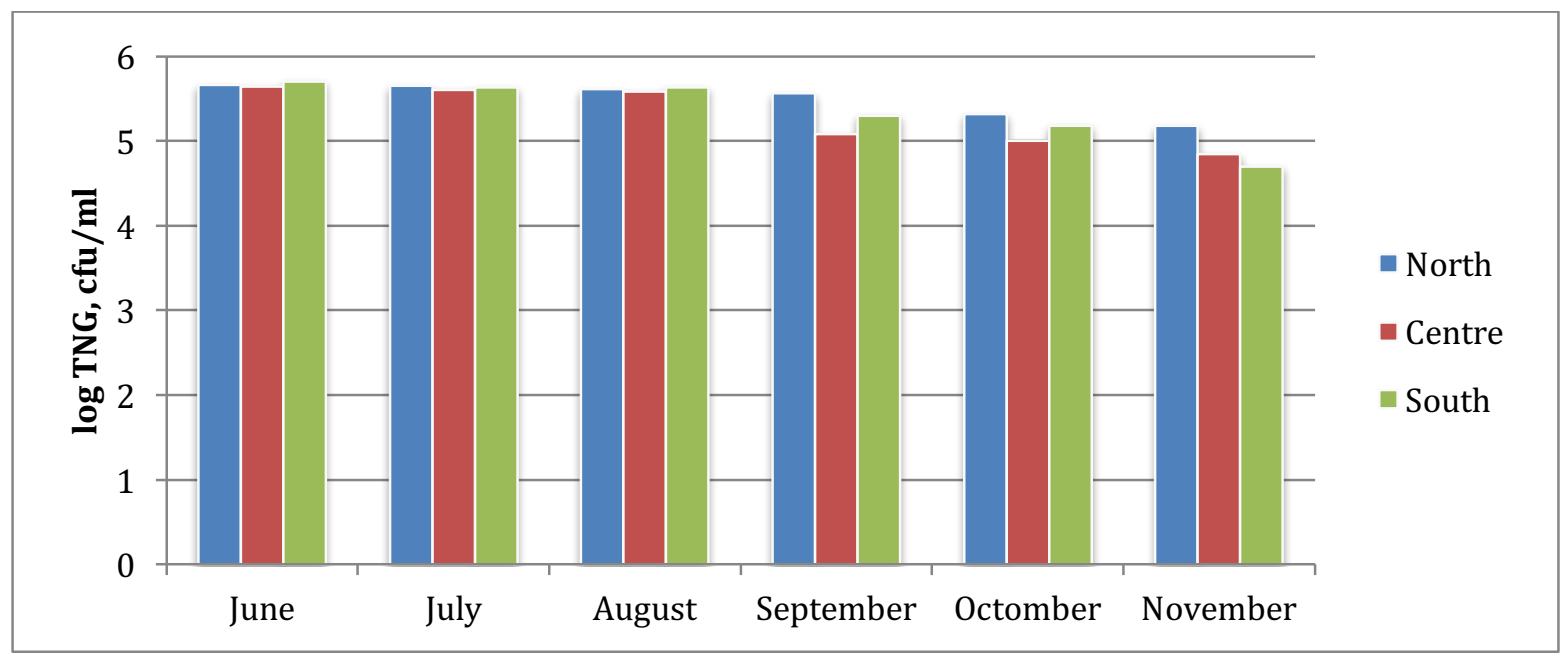

Figure 2. Evolution of the total number of microorganisms in goat milk during the summer autumn months

Milk, raw material for yogurt production has been tested for the presence of antibiotics and conservative substances for 5 days. Each day samples were taken from 3-4 lots.

Table 4. Control results of the anibiotics and inhibitory substances presence in raw milk

\begin{tabular}{|c|c|c|c|c|c|}
\hline \multirow{2}{*}{ Test } & \multicolumn{5}{|c|}{ Days } \\
\hline & 1 & 2 & 3 & 4 & 5 \\
\hline \multicolumn{6}{|c|}{ Presence of antibiotics } \\
\hline Methylene blue test & negativ & negativ & negativ & negativ & negativ \\
\hline Coagulation test & positiv & positiv & positiv & positiv & positiv \\
\hline Resazurin test & negativ & negativ & negativ & negativ & negativ \\
\hline \multicolumn{6}{|c|}{ Presence of conservative substances } \\
\hline The ferric chloride test & negativ & negativ & negativ & negativ & negativ \\
\hline Test with potassium iodide and starch & negativ & negativ & negativ & negativ & negativ \\
\hline Test with sulfuric and nitric acid & negativ & negativ & negativ & negativ & negativ \\
\hline
\end{tabular}

The quality of the goat's and cow's milk is satisfactory. According to the results obtained milk can be used in yogurt production. The principal mechanisms involved in the deterioration of processed foods are as follows:

Microbiological spoilage sometimes accompanied by pathogen development.

Chemical and enzymatic activity causing lipid breakdown, color, odor, flavor, and texture changes.

Moisture and/or other vapor migration producing changes in texture, water activity and flavor. 
Formulation and processing variables which affect these mechanisms and which can be used to control deterioration include: moisture and water activity; $\mathrm{pH}$; heat treatments; emulsifier systems; preservatives and additives; and packaging. Fluid milk and fermented milk products such as buttermilk, yogurt, and cottage cheese deteriorate because of: 1) bacterial growth and 2) lipid reactions, including both auto oxidation and enzymatic hydrolysis. The shelf life is usually from 7 to 14 days under refrigeration conditions (Park 2017).

Milk products are an ideal medium for growth of a number of psychrophilic bacteria. The optimum temperature for their growth is $20^{\circ}$ to $30^{\circ} \mathrm{C}$, but they also grow well, although more slowly, at refrigeration temperatures. Following pasteurization, it is generally only the more heat-resistant (thermoduric) bacteria, some of which can be psychrophiles that remain. Their numbers should be quite low, and at low temperatures $\left(0^{\circ}\right.$ to $\left.10^{\circ} \mathrm{C}\right)$, the milk should have a fairly long shelf life. Thus, the best way to prevent spoilage is to prevent recontamination after pasteurization. Growth of psychrophiles in milk can lead to a variety of off-flavors and defects (Application of Open Dating to Specific Foods).

Among these are bitter, fruity, rancid, stale, and putrid flavors, and ropiness in milk. One problem associated with establishing standards for acceptable levels of bacteria in milk is that different species produce different types and intensities of off-flavors and odors. The offflavors may be detected at $10^{4}$ colony forming units per milliliter $(\mathrm{cfu} / \mathrm{ml})$ of one species and not until $10^{7} \mathrm{cfu} / \mathrm{ml}$ of another species. The temperature coefficients $\left(\mathrm{Q}_{10} \mathrm{~s}\right)$ for microbial growth in milk range from 3 to 30 and average around 6. Enzymatic hydrolysis of triglycerides in milk can yield free fatty acids that cause rancid flavors even when present in very low concentrations. Lipase and other such enzymes are generally inactivated by pasteurization, but certain microbes can produce the enzymes as they grow. Oxidation of unsaturated fats and phospholipids can lead to a variety of off-flavors. Sunlight, fluorescent light, metal ions, excessive agitation as in homogenization, and a small amount of ascorbic acid and riboflavin favor or catalyze the oxidative reaction (Open Shelf-Life Dating of Food, Concept of Accelerated Shelf Life Study).

Table 5. Major Modes of Deterioration, Critical Environmental Factors, Shelf Life, and Type of Open Dating by Food Product

\begin{tabular}{|l|l|l|l|l|l|}
\hline \multicolumn{1}{|c|}{$\begin{array}{c}\text { Food } \\
\text { product }\end{array}$} & $\begin{array}{c}\text { Mode de } \\
\text { deterioration } \\
\text { (assuming an } \\
\text { intact package) }\end{array}$ & $\begin{array}{c}\text { Critical } \\
\text { environmental } \\
\text { factors }\end{array}$ & $\begin{array}{c}\text { Shelf life } \\
\text { (average) }\end{array}$ & $\begin{array}{c}\text { Date most } \\
\text { suitable } \\
\text { for } \\
\text { product }\end{array}$ & $\begin{array}{c}\text { Additional } \\
\text { information }\end{array}$ \\
\hline $\begin{array}{l}\text { Fluid milk } \\
\text { and product }\end{array}$ & $\begin{array}{l}\text { Bacterial growth, } \\
\text { oxidized flavor, } \\
\text { hydrolytic } \\
\text { rancidity }\end{array}$ & $\begin{array}{l}\text { Oxygen, } \\
\text { temperature }\end{array}$ & $\begin{array}{l}\text { 7-14 days at } \\
\text { refrigerated } \\
\text { temperature }\end{array}$ & Sell-by & $\begin{array}{l}\text { Length of time } \\
\text { product can } \\
\text { be stored at } \\
\text { home }\end{array}$ \\
\hline
\end{tabular}

The quality of starter cultures (lactic bacteria) has been assessed by determining the activity of lactic bacteria, monitoring the accumulation of lactic acid in the males used in the production.

The study was designed to determine microbial activity, lactic acid formation and $\mathrm{pH}$ decrease, respectively, during inappropriate storage of ticks. In the yoghurt production are used lyophilized SACCO YAB 352 B cultures consisting of lactic bacteria: Streptococcus thermophylus, Lb. bulgaricus (thermophilic homofermentative), Bifido bacterium animalis ssp.lactis (mesophilic heterofermentative), Lb. acidophilus (homofermentative mesophilus). In the case of Lactalux yogurt, starter cultures are used as Lyofast ST 430 - Streptococcus thermophylus and Lyofast ABC 1 blend containing Lb. acidophilus, Bifido bacterium animalis ssp. lactis and Lb. house (mesophilic heterofermentative optional). 
The storage conditions, and in particular the transport conditions, are often not met. Enhanced storage temperatures can affect starter cultures. Viability of bacteria is due to low storage temperature $\left(-18^{\circ} \mathrm{C}\right)$, temperatures at which cells go into the state of cryoanabiasis and can maintain activity for up to one year. The activity of lactic bacteria from the starter culture Sacco Probat 222 LYO was analyzed for 7 days at the Dairy Company under the terms of 2 conditions:

Probe sample 1 (Probat 1) - Appropriate storage conditions for starter cultures - refrigeration temperature $-18^{\circ} \mathrm{C}$;

Probe sample 2 (Probat 2) - Inadequate storage conditions for starter cultures - room temperature $\left(+22^{\circ} \mathrm{C}\right)$, humidity influence and $\mathrm{O}_{2}$.

When inoculating milk with these starter cultures, very low activity was observed for nonconforming stored samples.

Table 6. Modification of starter cultures acidity and $\mathrm{pH}$ kept under different conditions

\begin{tabular}{|c|c|c|c|c|}
\hline $\begin{array}{c}\text { Monitoring time, } \\
\text { hours }\end{array}$ & \multicolumn{2}{c|}{$\begin{array}{c}\text { Suitable storage conditions } \\
\text { (Probat 1) }\end{array}$} & \multicolumn{2}{c|}{$\begin{array}{c}\text { Inadequate storage conditions } \\
\text { (Probat 2) }\end{array}$} \\
\cline { 2 - 5 } & Titrable acidity, ${ }^{\circ} \mathbf{T}$ & $\mathbf{p H}$ & Titrable acidity, ${ }^{\circ} \mathbf{T}$ & $\mathbf{p H}$ \\
\hline 2 & 86 & 6.55 & 56 & 6.56 \\
\hline 4 & 90 & 6.0 & 70 & 6.4 \\
\hline 6 & 104 & 5.5 & 79 & 5.9 \\
\hline 8 & 120 & 4.7 & 82 & 5.3 \\
\hline 10 & 134 & 4.55 & 88 & 4.89 \\
\hline
\end{tabular}

The starter culture of Sacco Probat 222 LYO was subjected to the milk coagulation assay. Two coagulants with different organoleptic and physico-chemical characteristics were obtained. The coagulation process and the quality of the coagulum depend on the quality of the starter cultures used. The results are presented in Table 7.

Table 7. Starter cultures coagulation capacity

\begin{tabular}{|l|c|l|c|c|}
\hline \multirow{2}{*}{ Sample } & \multicolumn{4}{|c|}{ Characteristics } \\
\cline { 2 - 5 } & $\begin{array}{c}\text { Coagulation } \\
\text { time, hours }\end{array}$ & \multicolumn{1}{|c|}{ Coagulum consistency } & $\begin{array}{c}\text { The final titratable } \\
\text { acidity, }{ }^{\circ} \text { T }\end{array}$ & pH final \\
\hline Probat 1 & 8 & $\begin{array}{l}\text { curd homogeneous, dense, } \\
\text { moderately viscous }\end{array}$ & 134 & 4.55 \\
\hline Probat 2 & 15 & soft, homogeneous coagulum & 128 & 4.6 \\
\hline
\end{tabular}

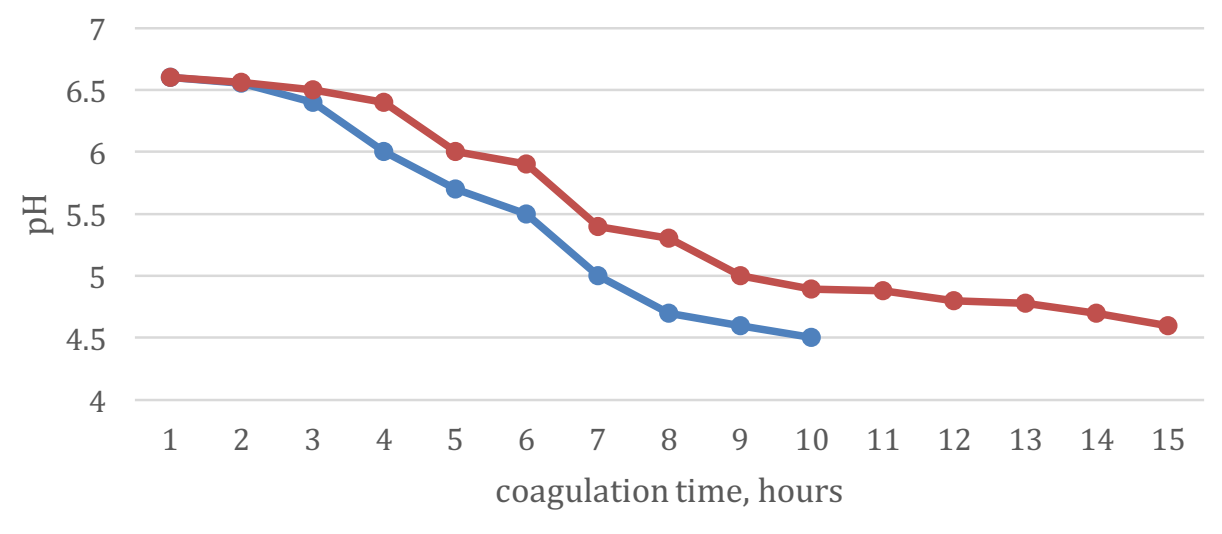

$\longrightarrow \mathrm{pH}$, suitable storage conditions $\longrightarrow \mathrm{pH}$, inadequate storage conditions

Figure 3.Fermentation curve (pH change), starter culture Probat 222 
For the manufacture and analysis of quality indices, 5 samples of classic yoghurt from the goat milk mix with cow's milk were proposed in the following proportions:

Table 8. Assortment of children classic yogurt

\begin{tabular}{|c|c|c|c|c|c|}
\hline $\begin{array}{c}\text { Nr. sample/ row } \\
\text { material (\%) }\end{array}$ & Sample 1 & Sample 2 & Sample 3 & Sample 4 & Sample 5 \\
\hline Cow milk & 100 & & 50 & 25 & 75 \\
\hline Goat milk & & 100 & 50 & 75 & 25 \\
\hline
\end{tabular}

Yogurt has been manufactured by the thermostat method (figure 4), being an effective method for the appreciation of the firmness formed curd, an important aspect of the acidic dairy products quality for children.

The coagulum of these products must be firm but at the same time fine to be easily assimilated by the body of the children. To assess the quality of the produced yoghurt, organoleptic, physicochemical and microbiological indices were determined. The recipe of yoghurt contains natural milk and starter culture, without any auxiliary material including stabilizers. Considering this, and given that they are acidic dairy products intended for small children, their shelf life is lower. 


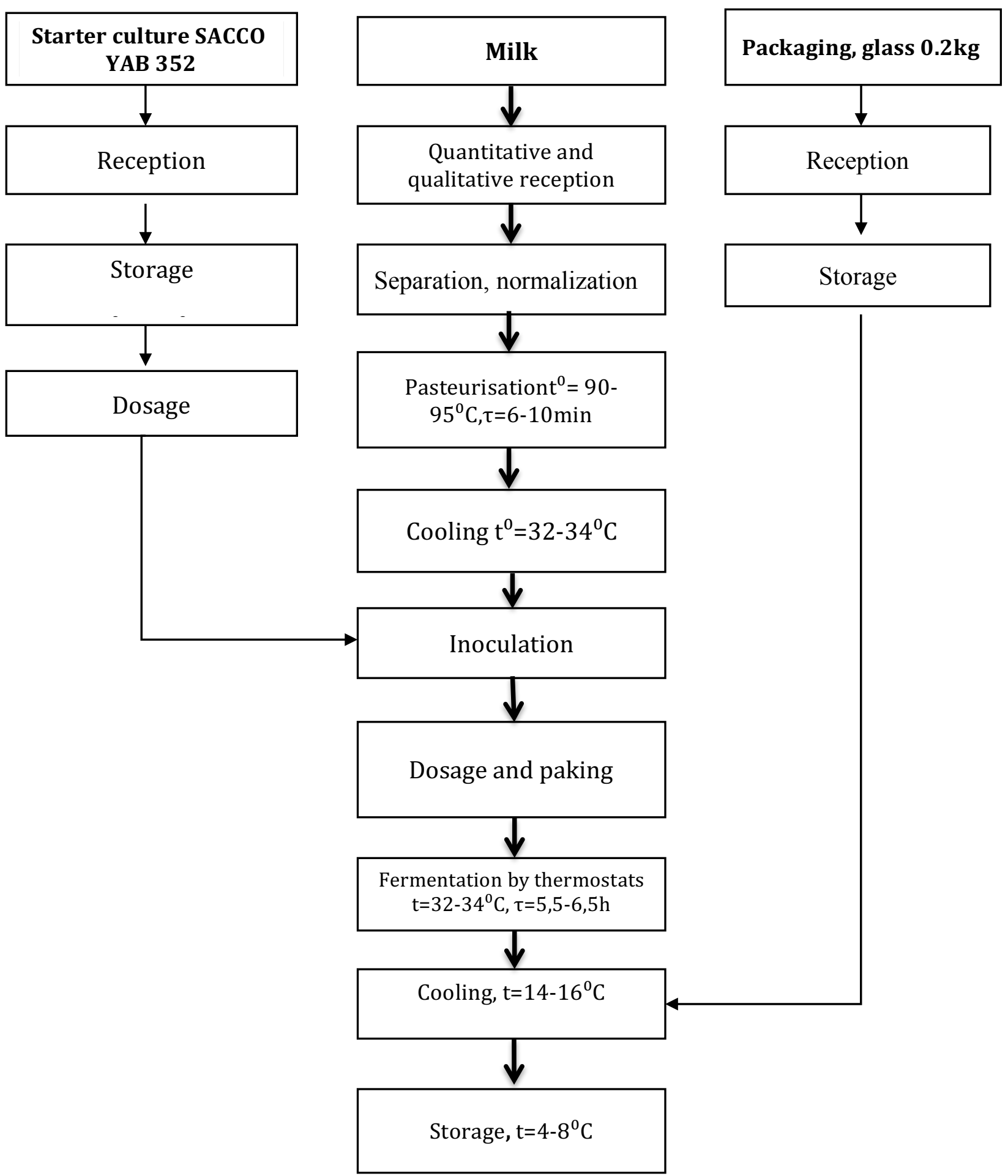

Figure 4. The technological scheme for making yoghurt for children by the thermostat method

Factors affecting quality of yogurt are the following:

1. Raw milk, skim milk, cream, sugar, cultures, milk concentrate, milk powders, fruit/fruit conserves, stabilisers, flavours and colours;

2. All can contribute micro-organisms and chemicals that affect the quality;

3. Changes in the source and supply will cause variation in factors that can influence shelf life;

4. Partnerships with approved suppliers and agreed specifications are recommended. 
The degree of syneresis indicates the amount of whey removed to the surface (\%) after the dairy products coagulation.

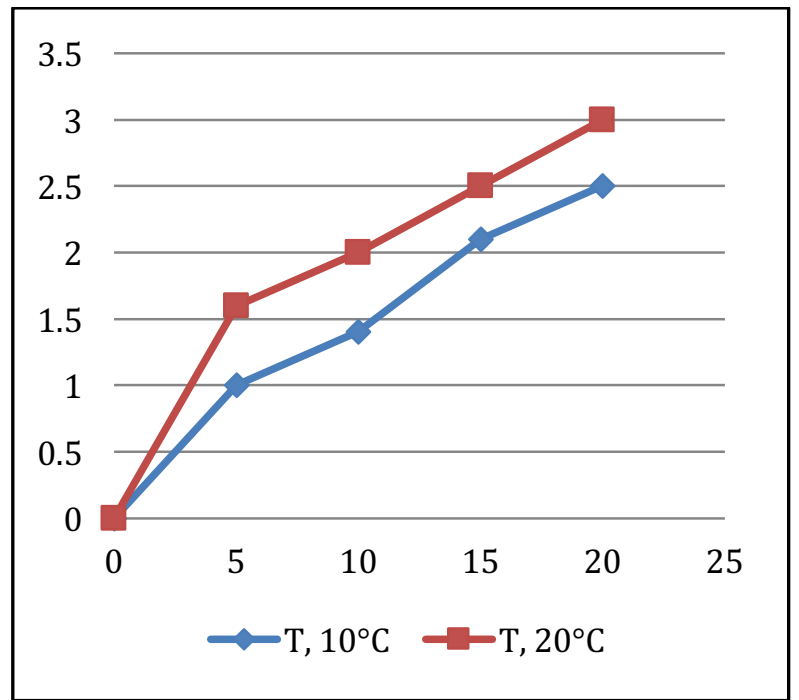

a)

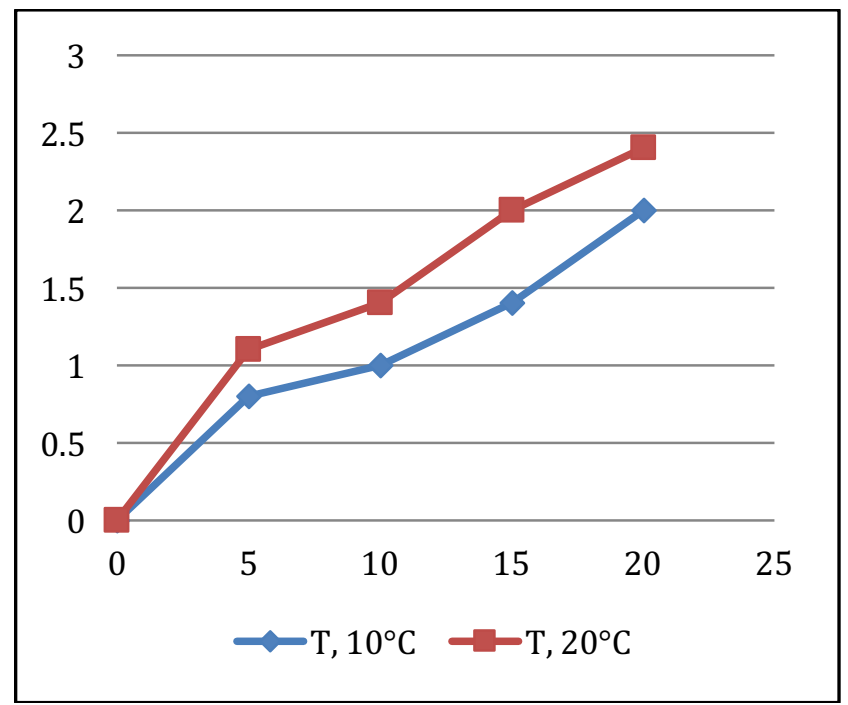

b)

Figure 5. Sineresi's values during storage

a) children's cow milk yogurt b) children's goat milk yogurt

The yogurt syneresis values were used to calculate the shelf-life $\mathbf{Q}_{\mathbf{1 0}}$ value, table 9.

Table 9.Syneresis in yogurt - effect of temperature during storage

\begin{tabular}{|c|c|c|c|c|c|c|c|c|c|c|c|}
\hline \multirow[t]{2}{*}{ Parameters } & \multicolumn{5}{|c|}{ Temperature $10^{\circ} \mathrm{C}$} & \multicolumn{5}{|c|}{ Temperature $20^{\circ} \mathrm{C}$} & \multirow{2}{*}{$\begin{array}{l}Q_{10} \\
\text { avarage }\end{array}$} \\
\hline & \multicolumn{10}{|c|}{ Whole milk yogurt } & \\
\hline Soragetime,days & 0 & 5 & 10 & 15 & 20 & 0 & 5 & 10 & 15 & 20 & \\
\hline Syneresis, mL/125g & 0 & 1.0 & 1.4 & 2.1 & 2.5 & 0 & 1.6 & 2.0 & 2.5 & 3.0 & \\
\hline \multirow[t]{2}{*}{$\mathbf{Q}_{10}$} & & & & & & & 0,63 & 0,70 & 0,84 & 0,83 & 0,75 \\
\hline & \multicolumn{11}{|c|}{ Goat milk yogurt } \\
\hline Soragetime,days & 0 & 5 & 10 & 15 & 20 & 0 & 5 & 10 & 15 & 20 & \\
\hline Syneresis, mL/125g & 0 & 0.9 & 1.2 & 1.9 & 2.4 & 0 & 1.3 & 1.6 & 2.2 & 2.8 & \\
\hline$Q_{10}$ & & & & & & & 0,69 & 0,75 & 0,86 & 0,86 & 0,79 \\
\hline
\end{tabular}

The most common and direct way of determining shelf-life is to carry out storage trials of the product under controlled conditions that simulate those it is likely to encounter during storage, distribution, retail display and consumer use. The method involves:

1. Identification of causes for spoilage of food;

2. Selection of suitable tests for determining spoilage of food;

3. Planning of shelf life study;

4. $\quad$ Running the shelf life study;

5. Determination of the shelf life;

6. Monitoring the shelf life.

There are three main categories of food spoilage physical, chemical, and microbiological. List out all the possible ways by which product may deteriorate in quality and/or safety (Sandulachi and Bulgaru 2016).

An acceptable shelf-life is expected to retain desired sensory, chemical, functional, microbiological and physical characteristics of the product. All tests are not appropriate for all products. For example, one may test milk for numbers of lactic acid bacteria but not fermented 
milks for these organisms. In general, tests can be divided into four categories viz. sensory, physical, chemical and microbiological.

Sensory evaluation assesses taste, smell, appearance, and texture of food. It can be used to monitor and record obvious changes that occur over time. Therefore, it is useful when determining the shelf life of a food. Physical tests include tests for measuring product density, viscosity, refractive index conductivity, surface tension, light absorption, redox potential, microscopic examination, etc. Chemical tests can detect changes in quality of the product throughout its shelf life. Examples of chemical tests include acidity, free fatty acids soluble nitrogen, peroxide value and headspace gas analysis. Microbiological-these tests can be used to evaluate both food quality and safety. Tests may be done to estimate changes in the number and type of spoilage organism (yeasts, moulds or bacteria) occurring over time.

To assess the quality of the produced yoghurt, organoleptic, physicochemical and microbiological indices were determined.

Quality indices of children goat milk and cow's milk yogurt are shown in the table 10.

Table 10. Children yogurt of goat and caw milkquality indices.

\begin{tabular}{|c|c|c|c|c|c|c|}
\hline \multirow[b]{2}{*}{ Nr. } & \multirow[b]{2}{*}{ Characteristics } & \multicolumn{5}{|c|}{ The experimental value } \\
\hline & & $\begin{array}{l}\text { Sample } \\
1\end{array}$ & Sample 2 & Sample 3 & Sample 4 & Sample 5 \\
\hline \multicolumn{7}{|c|}{ Physico-chemical indices } \\
\hline 1. & Dry substance, \% & 14 & 15.5 & 17.5 & 19.5 & 17 \\
\hline 2. & Protein content, \% & 2.23 & 2.49 & 3.76 & 2.69 & 2.56 \\
\hline 3. & Fat content, \% & 3,7 & 4.1 & 4.25 & 3.9 & 3.2 \\
\hline 4. & Viscosity, $\mathrm{m}^{2} / \mathrm{s}$ & $3.0^{*} 10^{2}$ & $2.6 * 10^{2}$ & $3.2 * 10^{2}$ & $2.1 * 10^{2}$ & $2.9 * 10^{2}$ \\
\hline 5. & Titrable acidity, ${ }^{\circ} \mathrm{T}$ & 80 & 100 & 110 & 120 & 100 \\
\hline \multicolumn{7}{|c|}{ Microbiological characteristics } \\
\hline 6. & $\begin{array}{l}\text { Total number of } \\
\text { microorganisms, } \\
\mathrm{cfu} / \mathrm{ml}\end{array}$ & $2 * 10^{7}$ & $1.5 * 10^{7}$ & $1.8^{*} 10^{7}$ & $1.6^{*} 10^{7}$ & $1.8 * 10^{7}$ \\
\hline 7. & Yeast and mold & absence & absence & absence & absence & absence \\
\hline \multicolumn{7}{|c|}{ Sensory characteristics } \\
\hline 8. & $\begin{array}{l}\text { Appearance and } \\
\text { consistency }\end{array}$ & \multicolumn{5}{|c|}{ liquid, moderately viscous undamaged curd } \\
\hline 9. & Taste and smell & \multicolumn{5}{|c|}{ lactic taste, without foreign smell and taste } \\
\hline 10. & Color & \multicolumn{5}{|c|}{ white, in the sample $1,3,5$ with yellow shades } \\
\hline
\end{tabular}

The dry matter content depends on the content of proteins, minerals, fats. The higher their concentration, the higher values has dry substance. Maximum values of dry matter content were obtained for sample 4 and 5 . Sample 3 shows the maximum values of viscosity than the other samples. This is due to the fact that the protein content in the sample is much higher and the coagulum was obtained as a strong one as sample 1 . The lowest values were obtained for sample 2 - 100\% goat milk yoghurt. According to the researches carried out (Boza J. Et al., 2009), the casein micelles in goat milk differ from those in cow's milk, having a higher $\beta$-casein solubility, more calcium and phosphorus, and a lower stability to heat treatment. This is why the coagulum is softer and influences the duration of digestion, because in the acidic environment of the gastrointestinal tract it forms smaller and softer clusters than cow's milk, which is an advantage for the children's body. The highest acidity values correspond to samples 3 and 4. Titrable acidity depends on the lactic acid content obtained of lactic acid fermentation by lactic bacteria. Thus, the more lactose is in milk, the more lactic acid is produced and the acidity will increase. Normative values for yoghurt range from $85-120^{\circ} \mathrm{T}$. If 
these values exceed the normative limit in the analyzed product, this is an indication that the product is no longer safe for consumption. The total number of germs determined for the yogurt samples falls within the yogurt-specific normative values. Yeasts and molds have not been detected.

Sensory characteristics of the products were analyzed by method 5 points according to the quality requirements under existing documents (MS ISO 22935-3: 2015).

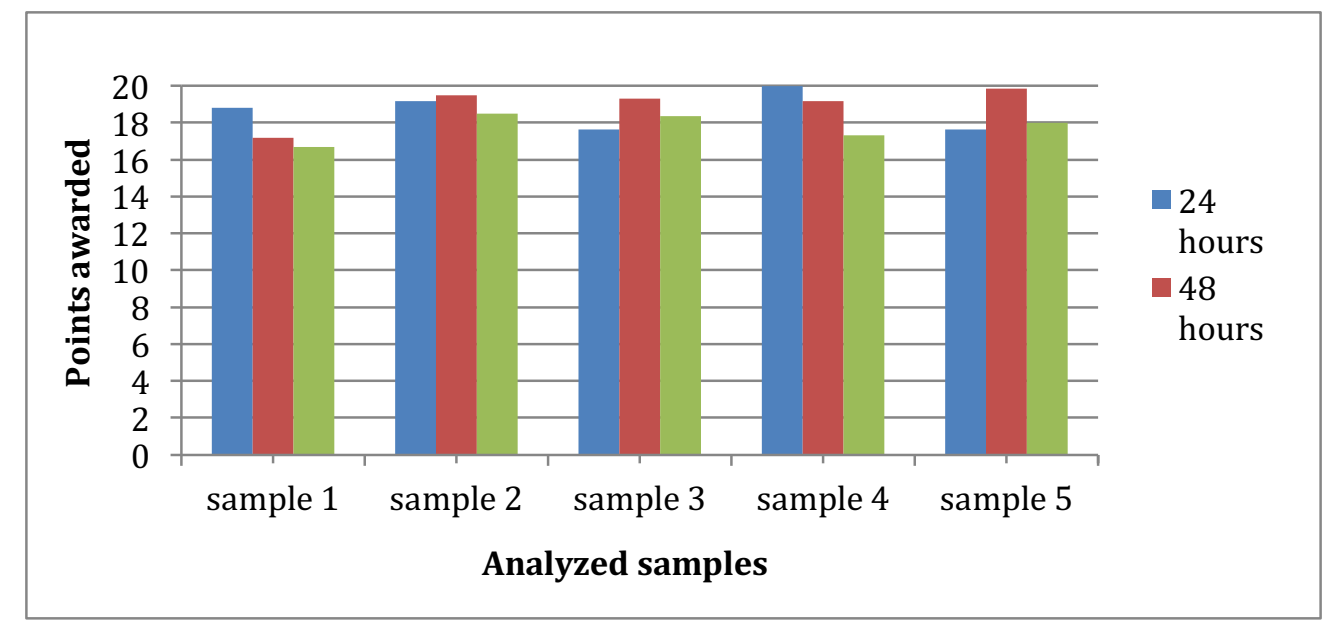

Figure 6. Sample's sensory quality variation for 72 hours.

The yoghurt samples have an average score of 20 points and according to their scoring scale they are given the "very good" and "good" qualifier and can be characterized as "Product with pleasant, specific, well-defined traits, non-defective sensory perceptible". The visible defects from sensory analysis were fat-to-surface separation in samples where the cow's milk content was $100 \%, 50 \%, 75 \%$. These defects are due to the lack of a homogenization process that aims at transforming fat globules of $\approx 15 \mu \mathrm{m}$ in size into small ones between $0.2-1 \mu \mathrm{m}$. As a result of this process the defect of fat separation on the surface disappears, the color becomes white with creamy shades.

\section{CONCLUSIONS}

Goat milk has changes in microbial load according to genetic factors, environmental conditions and agricultural practices.

Goat milk is considered to be superior to cow's milk due to its nutritive, tonic, anti-anemic and anti-infectious effects. Also, goat's milk has a lower casein content and a lower coagulation capacity and higher digestibility. Because of these characteristics, goat's milk is recommended in the diet of a wider group of consumers, including children. In children's diet, dairy products are the most important source of minerals and vitamins.

From goat's milk can be obtained children fermentative products, including yoghurts. Their quality and safety depend on several factors: the raw materials (milk)quality, the used starter cultures, the strict observance of the technological parameters and the storage conditions. Sensory quality is an important indicator for consumers, especially for children. Therefore, great attention should be paid to the taste, consistency, stability of the product over time.

Based on the study, we conclude that goat milk can serve as a source for diversifying food for children. By complying with all the quality and safety requirements, products that are beneficial to children's health can be obtained. 


\section{References}

Alfe' Rez, M. J. M., Barrionuev O, M., Lo' Pez-Aliaga, I., et al., (2001) Digestive utilization of goat and cow milk fat in malabsorption syndrome. Journal of Dairy Science. Ed. 64, 451-461p.

Aliaga, L., Alferez, M., Barionuevo, M., (2000). Influence of goat and cow milk on the digestive and metabolic utilisation of calcium and iron. J Physiol Biochem 56, 201-208.

Bevilacqua, C. (2001) Goats' milk of defective alpha(s1)-casein genotype decreases intestinal and systemic sensitization to beta-lactoglobulin in guinea pigs. Journal of Dairy Research 68, 217-227 p.

Bulgaru, V., Botezat, O.(2018). The quality indices of yaghurt manufactured with cow milk and goat milk. International conferince Modern technology in food products ed. IV, Chișinău, ISBN 978-9975-87-428-1.

Bulgaru, V. (2016). Quality of local goat milk depending on the season.Revista Meridian Ingineresc, nr.4.

Boza, J., Sanz- Sampelayo, M. R. (2009). Composition of goat and cow milk produced under similar conditions and analyzed by identical methodology. Journal of Food Compozition and Analysis. Volume 22, Issue 4.

Cupakova, Š.,Pospišilova, M., Karpiškova, R., Janštova, B., Vorlova L. (2012), Microbiological quality and safety of goat's milk from one farm.Actauniversitatisagriculturae et silviculturaemendelianaebrunensis. Volume LX 4 Number 6.

Foschino, R., Invernizzi, A., Barucco, R.,Stradiotto, K. (2002). Microbial composition,including the incidence of pathogens, of goat milkfrom the Bergamo region of Italy during a lactationyear. The Journal of Dairy Research, 69 , 2: 213-225.ISSN 0022-0299.

Haenlein, GFW, Caccese, R. (1984).Goat milk versus cow milk. In: Haenlein GFW, Ace DL (eds.) Extension Goat Handbook. USDA Publ. Washington DC, pp: 1:1-4.

Haenlein GFW (1992) Role of goat meat and milk in human nutrition. In:Proceedings of the 5th International Conference on Goats. 2: 575-580.

Haenlein, G., et al. (2001), Past, present, and future perspectives of small ruminant dairy research. Journal of Dairy Science. Ed. 84, 2097-2115p.

Hassan LK, Haggag HF, El Kalyoubi MH, EL-Aziz MA, El-Sayed MM, Sayed AF.(2015), Physico-chemical properties of yoghurt containing cress seed mucilage or guar gum. Annals of Agricultural Science. 60(1):21-8

Hernández-Ledesma, B., Ramos, M., Gómez-Ruiz, J.A. (2011) Bioactive components of ovine and caprine cheese whey. Small Ruminant Research 101, 196-204.

Ivana, Simona, Bogdan, I., Țogoe, G., Câmpeanu, T., Enache, S., Bărăitareanu, I., Ipate, A. Popescu. (2011). Microbiologiaalimentelor, Volumul I, Ed. Asclepius, Bucureşti

James, Th., (2015). Physicochemical Properties, Microstructure and Probiotic Survivability of Non-Fat Goat's Milk Yogurt Using Heat Treated Whey Protein Concentrate as a Fat Raplacer. University of Vermont, dissertations, 78 p.

Jenness R (1980) Composition and characteristics of Goat Milk: AReview. J DairySci 63: I968-1979.

Muehlherr, J. E., Zweifel, C., Corti,S., Blanco, J. E., Stephan, R. (2003).Microbiological quality of raw goat's and ewe'sbulk-tank milk in Switzerland.Journal of DairyScience, 86, 12: 3849-3856. ISSN 0022-0302.

Park, YW. (1994).Hypo-allergenic and therapeutic significance of goat milk. Small Rumin. Res. 14:151-159.

Park, YW (2006) Goat Milk- Chemistry and Nutrition. In: Park YW, Haenlein GFW (eds.) HandbookofMilkofNonBovineMammals.

Park, Y.W., Juarez, M., Ramos, M., Haenlein, G.F.W. (2007).Physico-chemical characteristics of goat and sheep milk. Small Rumin Res., 68:88-113.

Park, YW, Jeanjulien, C., Siddique, A. (2017). Factors Affecting Sensory Quality of Goat Milk Cheeses: A Review.J Adv Dairy Res 2017, 5:3. ISSN:2329-888X

Peres, C., Tacito, L. A., Rodrigo, P. L. (2016) An evaluation of the physicochemical, microbiological and sensory properties of goat cheese. African Journal of Dairy Farming and Milk Production ISSN: 2375-1258 Vol. 3 (1), pp. 120-125, January. Available online at www.internationalscholarsjournals.org (C) International Scholars Journals.

Patermann, C. (2005). EU Strategies for life sciences and biotechnology research. // 3rd Moscow International Congress "Biotechnology: state of the art and prospects of development", Moscow.

Ried, K. (2004).Gastrointestinal health. The role of pro- and pre-biotics in standard foods. //Aust. Farm. Physician. 33(4): 253-255. 
Sandulachi, L., Bulgaru, V, (2016). Microbiologia generală. Note de curs. Partea III, Chișinău, Editura Tehnică-UTM. 63p., ISBN 978-9975-45-438-4

Sandulachi, L., Rubțov, S., Popescu, L., Costiș,V., Gurmeza, I. (2017) Controlulmicrobiologicalproduseloralimentare. Indicațiimetodiceprivindcontroalelemicrobiologice, Chișinău, EdituraTehnică-UTM, 128p. ISBN 978-9975-45472-8.

Senderov, B. (1998) Meditinscaia microbnaia ecologhia i functionalinaia pitaniea. Editura Granti.

Taftă. V.(2001)Producţiaşireproducţiacaprinelor. EdituraBucureşti: CERES,1996, p.190

Tilahum, Z., Nejash, A., et al. (2014). Review on medicinal and nutritional values of goat milk. Academic Journal of Nutrition 3 (3), 30-39 p. ISSN 2309-8902.

FAOSTAT. (2013). FAO Statistical Yearbook 2013,World Food and Agriculture, Food and Agriculture Organization of the United Nations.

USDA (1976) Posati LP, Orr M.L. Composition of Foods. Dairy and Egg Products. Raw, Processed, Prepared, in: Agricultural Handbook No. 8-1.ARS, USDA, Washington, DC.

www.statistica.md

Open Shelf-Life Dating of Food

https://www.princeton.edu/ ota/disk3/1979/7911/7911.PDF

Concept of Accelerated Shelf Life Study http://www.foodtestingindia.com/concept-accelerated-shelf-life-study-2/

Determination of titratable acidity in milk according to DIN 10316 and in yoghurt according to ISO/TS 11869 and IDF/RM 150

Determination of fat content by the gravimetrică method, SM EN ISO 1211:2015

Determination of milk protein content. Kjeldah method ISO 8968-1:2014 - IDF 20-1:2014

Determination of total dry matter content. (MAC Humidity Analyzer, Radwag).

American Public Health Association. 1993. Standard Methods for the Examination of Dairy Products, 16 th ed. APHA, Washington, DC

Manual analitic bacteriologic (BAM). FDA. Food \& Drug.

http://www.fda.gov/Food/FoodScienceResearch/LaboratoryMethods/ucm2006949.htm

American Public Health Association . 1984. Compendium of Methods for the Microbiological Examination of Foods, 2nd ed. APHA, Washington, DC

American Public Health Association .1993. Standard Methods for the Examination of Dairy Products, 16 th ed. APHA, Washington, DC

SM EN ISO 4833-1:2014 Microbiologia lanţului alimentar. Metoda orizontală pentru enumerarea microorganismelor. Partea 1: Tehnica de numărare a coloniilor la $30^{\circ} \mathrm{C}$ prin metoda turnării în plăci.

SM EN ISO 4833-2:2014 Microbiologia lanţului alimentar. Metoda orizontală pentru enumerarea microorganismelor. Partea 2: Tehnica de numărare a coloniilor la $30^{\circ} \mathrm{C}$ prin metoda însămânţării la suprafața plăcii.

SM EN ISO 6579:2013 Microbiologia produselor alimentare şi furajelor. Metoda orizontală pentru detectarea bacteriilor de genul Salmonella spp.

Determinarea numărului de bacterii mezofile aerobe și facultativ anaerobe, conformSM EN ISO 4833-1, SM EN ISO 4833-26.14

Association of Official Analytical Chemists. 1990. Official Methods of Analysis, 15th ed. AOAC, Arlington, VA TR TC 033/2013.TC Règlement Technique "Sur la sécurité des produits laitiers et leurs dérivés" (TR TC 033/2013)http://www.ccis-expertise.com/fr/tr-tc-033-2013-securite-des-produits-laitiers-et-leurs-derives

Prelevarea probelor şi pregătirea lor pentru analiza microbiologică, conform SM SR EN ISO 6887-1, SM SR EN ISO 6887-5:2014.

Determination of somatic cell number according to SR SR EN ISO 13366-2 or SR SR EN ISO 18330.

Determination of pasteurization (phosphatase assay) according to SM EN ISO 22160

SM EN ISO 22160: 2015 Milk and milk based drinks. Determination of alkaline phosphatase activity. 